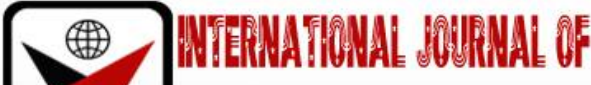

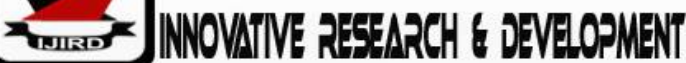

ISSN 2278 - 0211 (Online)

\section{Domestic Debt Management and Government Revenue in Nigeria}

\begin{tabular}{c}
\hline Dr. T. O. Asaolu \\
Lecturer, Department of Management and Accounting, \\
Obafemi Awolowo University, Ile-Ife, Osun State, Nigeria \\
Dr. I. S. Akinadewo \\
Lecturer, Department of Directorate, IAC Academy Limited, Nigeria \\
Dr. G. E. Oyedokun \\
Lecturer, Department of Taxation, Nasarawa State University, Nigeria \\
\hline
\end{tabular}

\begin{abstract}
:
The study examined the impact of domestic debt management on government revenue in Nigeria. The study employs primary data through questionnaire, administered to respondents. The sample size was 306, which was determined through Krejcie \& Morgan (1970) formula. Logit regression technique was used for data analysis. The results reveal that domestic debt management proxied by Effective Debt Maturity Policy (EDMP), Effective Management of Inflation and Monetary Instability (EMIMI), Transparency and Accountability in Government (TAG), and Interest Rate Control and Effective Management of Debt Structure (IRCEMDS) has a positive relationship with government revenue as the tcalculated of 0.591 is greater than $t$-tabulated of 0.560 at $5 \%$ level of significance, but not statistically significant. This is shown with the $P=0.528>0.05$ with $t$-statistics of 0.591 . The empirical investigation shows that domestic debt management will have inverse relationship with inefficiency in government revenue utilization. The study recommends among others for a more proactive domestic debt management team for better utilization of government revenue.
\end{abstract}

Keywords: Budget financing, domestic debt management, Government revenue, Interest rate

\section{Introduction}

In the recent years, the Nigeria's annual budgets have been partly financed with public debt. This is through the foreign and the domestic loans. The socio-economic plans of Nigeria have led to increased level of domestic debt. Thus, this expansionary policy of the government became the financing of deficit budget with domestic borrowings (Adofu \& Abula, 2010). The expansionary policy is to grow the economy through investing in productive sectors/ventures, increase in employment, allowing private investment and maintain an attainable and sustainable revenue base, among others. The major revenue of government in Nigeria is from the sale of petroleum products, and other non-petroleum revenue from taxes, among others. Consequently, the shrinking revenue through unanticipated declines in its collection have contributed to the recourse to borrowing (Esien, Agboegbulem, Mba \& Onumonu, 2016; Irabor, 2011; Adofu \& Abula, 2010). The policy makers including the scholars have, however, been concern of the negative effect of the rising domestic debt on the major revenue driver of the economy (Ngerebo-A, 2014). Thus, when government borrow indiscriminately without efficient management of the service cost, it will lead to consequential debt overhang and debt problem (Irabor, 2011). The scholars have also posited that the rising domestic debt in Nigeria is partly due to its inefficient management and corruption (Ayuba \& Khan, 2019; Eyide \& Nzewi, 2018; Okwori \& Sule, 2016).

In Nigeria, the domestic debt has been accelerating both in loans and service cost. Thus, the debt that was N3,228.03 billion in 2009 rose to N12,774. 41 billion in 2018. The interest charges also moved upward from N271, 540.13 million in 2009 to N1,797.90 billion in 2018 (DMO, 2018). Consequently, this has led to severe economic problems like fall in the standard of living, increase in unemployment, and poverty, among others, which is due to low economic growth rate (Ewubare, Nteegah \& Okpoi, 2017; Irabor, 2017). This has resulted in the debate among the public finance stakeholders on the need to re-examine the existing domestic debt management method for a more effective and efficient policy. This will be with the intent of evaluating the interest rate, the inflation, transparency and accountability in government, and debt structure, among others.

Thus, this study set out to examine the relationship between domestic debt management and government revenue in Nigeria. This aims at proffering possible solution to the rising domestic debt and its impact on the revenue of government. 


\section{Literature Review}

\subsection{Measurement of Domestic Debt Instruments on Government Revenue}

The measuring of domestic debt instruments on government revenue involves the efficient appraisal of the key variables for effective attainment of the planned objectives. The instruments include: The effective management of domestic debt will be better achieved through the measurement of domestic debt instruments on government revenue. This will enable an effective attainment of government's planned socio-economic objectives. Consequently, the evaluation of the effectiveness of debts instruments is necessary for the primary purpose of ensuring that these are appraised towards effective domestic debt management. The domestic debt instruments include treasury certificates, treasury bills, federal government development stocks, treasury bonds, among others (Irabor, 2011; Ude \& Ekesiobi, 2014). Every debt has the date of maturity. Thus, when loans are taken by government, the purpose of that loan will determine the agreeable maturity. Debt managers also consider the risk involved in term of the loans - short term, medium and long term, in adequately determining the effective maturity policy. The debt managers, however, tend to take preference for long term than short term maturity because of their concern for the risk of refinancing at higher than expected interest rate (Missale, Giavazzi \& Benigno, 2000). Accordingly, when long-term rates are high relative to their expectations, they issue short maturity debt to minimize borrowing costs (Missale, Giavazzi \& Benigno, 2000). Thus, when nations borrow to finance projects, government purposed to effectively manage the relative debt and the associated risk for economic growth.

The huge fluctuations in revenue of government have been majorly attributed to the impact of economic and political events occurring in western countries (AfDB, 2013 cited by Ayuba \& Khan, 2019). This cut in revenue encouraged the nations to engage in borrowing to increase the level of revenue especially when financing governmental fiscal budgets (Ayuba \& Khan, 2019). Thus, the primary purpose of effective debt maturity is to ensure that the amount borrowed to increase the revenue, achieves the plan for economic growth and to avoid a mismanagement which will put pressure on that same revenue. It is therefore expected that effective debt maturity policy will positively impact the revenue of government.

Jeanne and Guscina (2006) opined that monetary instability curtails the ability of government to finance public debt with domestic borrowing. The level of inflation is also a key factor for consideration in regressing domestic debt management on government revenue. If inflation goes up, then the economic purchasing power reduces with relative effects on meeting the domestic debts obligations. The effective management of inflation and monetary instability is expected to positively influence government revenue and vice versa. The ineffective control of inflation and the instability in monetary policies of government do not only affect government revenue but also discourage inflow of investment. Thus, the resultant effect is retardation in economic development.

Scholars have argued that lack of transparency and accountability in Nigeria have led to the mismanagement of the revenue of government including public debt (Adofu \& Abula, 2010; Okwori \& Sule, 2016). Thus, to achieve the economic growth envisaged in public debt borrowing for project financing, there should be transparency not only in the process but also in the utilization. When there is transparency in the process, the managers will be more accountable in the use of the borrowed fund for the intended and guide against fund diversion. Consequently, the expectation is for transparency and accountability to positively influence the revenue of government.

The low rate of interest administered on debts instruments for a longer period has been established as one of the problems of debt management in Nigeria (Yusuf, Idowu, Okunnu \& Adeyemi, 2010). Interest rate could be variable or fixed and this will determine the extent at which it is controlled for effective management. The debt structure requires adequate arrangement in the actualization of the objectives of borrowing. Thus, the inappropriateness in debt structure will adversely affect the revenue of government with increased debt profile and economic slump. Consequently, effective management of debt structure and interest rate control is expected to positively influence government revenue.

\subsection{Budget Financing Through Borrowing}

The use of borrowed fund to finance the budget of government came because of the inability to generate enough revenue to meet up with the annual and periodic plans of the state. Thus, nations embark on borrowing when they find it impossible to generate adequate domestic savings to boost their economic developmental plans (Essien, Agboegbulem, Mba \& Onumonu, 2016). The concern of the state to grow the economy brought about the intention to channel funds into productive sectors. Thus, investment and channeling of funds to productive sectors is expected to drive the economy in the appropriate path for the improvement of the wellbeing of the citizens. Whilst there are conditions attached to the use of loans for project financing, especially the interest cost, it is expected that the benefits accruable thereafter, will overshadow the initial cost. Consequently, the use of loans for this purpose has accumulated public debt both externally and internally. The foreign debt is the accumulated financial obligations to foreign lenders. This includes the International Monetary Fund (IMF), Paris Club and World Bank, among others. The domestic debt on the other hand is the financial obligations to internal lenders. The resort by government to obtaining loans internally is assumed to be for the protection of the sovereignty of nations due to the stringent conditions on foreign loans. Panizza (2008) stressed, however, that it is a difficult task to obtain adequate data on the composition of public debt of emerging economies.

\subsection{Ricardian Equivalence Theory (RET)}

This is an economic theory which postulates that the government could stimulate the economy through increase in debt for the financing of government spending, while the demand remains constant (Osodiuru, Odo, Ugwuoke \& Chikwendu, 2018). This theory was propounded by David Richardson in the 19th century but was more elaborately conceptualized by Barro in 1989 (Osodiuru, Odo, Ugwuoke \& Chikwendu, 2018, citing Barro, 1989). Barro model posits 
that consumers' lives and other needs for their generations are infinite (Ricciuti, 2001). Consequently, they act in a way to suggest limitless lives, presupposes that the bonds issued, the repayment and the related interests that the consumers receive equal to the aggregate of the principal and taxes levied to pay interest (Ricciuti, 2001).

Accordingly, the downward movement in government savings will be totally eroded by the increase in private savings, leaving constant, the national savings (Ricciuti, 2001). Thus, this theory argues that fiscal policy is ineffective, which is as a result of the underlying concept that any increase in the spending of government, which implies upward movement of taxes, will attract increase in household savings, which then eliminates the effect of the increase in government spending (Osodiuru, Odo, Ugwuoke \& Chikwendu, 2018). Karazijiene (2015) however, argues that the Ricardian Equivalence Theory states that there is no difference in the economy how the country is covering its expenses (by taxes or by borrowing). Thus, investment would not change even if taxes were reduced by certain amount and the corresponding amount was borrowed in maintain the expenditure of the nation at same level (Karazijiene, 2015).

\subsection{Conceptual Framework}

A conceptual framework was created for this study in establishing the relationship between independent and dependent variables as follows:

Government Revenue (GR) is the dependent variable, while Domestic Debt Management (DDM) is the independent variable

The independent variable is proxied by the following:

EDMP = Effective Debt Maturity Policy

EMIMI = Effective Management of Inflation and Monetary Instability

TAG = Transparency and Accountability in Government

IRCEMDS = Interest Rate Control and Effective Management of Debt Structure

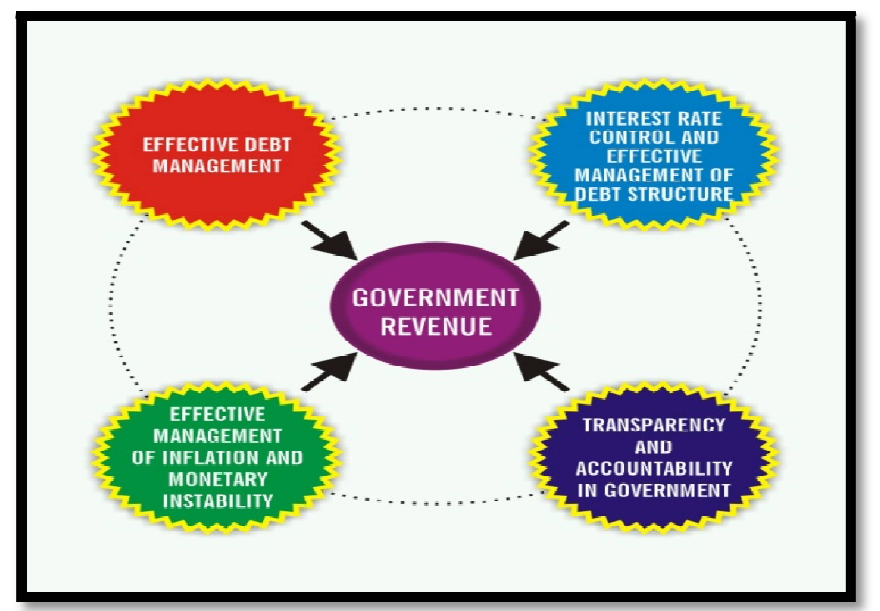

Figure 1: Components of Conceptual Framework for the Model Source: Authors' Model Conceptual Framework (2020)

\subsection{Empirical Review}

The Debt Management Office (DMO) reports annually on public debt profile in Nigeria. The recent development, however, shows that the domestic debts have been on the increase, which has elicited interests from the scholars. Whilst public debt including the domestic debt are sometimes classified as inclusive of the revenue of government, it has been established that the mismanagement of this could adversely affect other revenue sources of government (Ngerebo-A, 2014; Adofu \& Abula, 2010; Okwori \& Sule; 2016). In the efforts to find solutions to this negative impact of domestic debt on government socio-economic plans, scholars have researched on domestic debt in relationship to other variables. There have been studies on the relationship between domestic debt and economic growth and the effect of government revenue on economic growth in Nigeria (Fasoye, 2018; Imimole \& Imoughele, 2012; Raifu \& Raheem, 2018). In these studies, there have been few studies as to the impact of domestic debt management on the other government sources of revenue. For instance, Fayose (2018) examined the profile of Nigeria's domestic debt between 1980-2017 using pooled OLS regression technique. The study reveals that holding of government's internal debt outstanding in the economy portends a huge fiscal problem if the government access larger part from the banking sector.

Imimole \& Imoughele (2012) examined the continuous increase of domestic debt profile in Nigeria, the effect on economic growth and on the crowding-out of private lending. The study adopts the OLS regression technique and time series data (1980-2009) to evaluate the modified Barro Growth Model. The study reveals that domestic debt in Nigeria has an inverse and significant impact on economic growth. Ngerebo-A (2014) investigated the relationship between domestic debt and the poverty level of Nigeria for the period 1986-2012. The study used OLS, Vector Auto Regression, Cointegration and Granger Causality Approaches to analyse the data. The study shows a long-run relationship between poverty (measured by real gross domestic product), per capital gross domestic product and domestic debt in Nigeria.

Ude and Ekesiobi (2014) investigated the empirical issues relating to domestic debt structure and composition and the impact on private investment in Nigeria. The study employed secondary data with the use of multiple regression models from 1970-2012. The study reveals that domestic debt has an inverse significant effect on domestic private 
investment in Nigeria. The results also show that domestic debt has inverse significant effect on foreign private investment with exchange rate and debt servicing having positive impact on foreign investment in Nigeria.

Dooley (2000) examined the management of debt and crisis in developing economies. The study reviewed debt management policy; portfolio management in an imperfect world; multiple equilibrium; default risk and developed a sovereign debt model. The finding of the model suggests that minimizing of debt service costs would likely be inefficient for developing economies because such a policy increases the cost of default.

Okwori and Sule (2016) appraised the sources of revenue in Nigeria with the inclusion of public debt to ascertain the effect on economic growth. The study employed Co-integration Test and Granger Causality test to appraise the longrun relationship between revenue sources and to examine the direction of the relationship between sources of revenue and economic growth. The findings reveal that oil and non-oil revenue exert positive effects on economic development in Nigeria. External debt, however, shows positive indicator and statistical significance.

Despite the plethora of studies on domestic debt, there is still scantiness on how it affects other government revenue in Nigeria, most especially with the adoption of the components of the independent variables for efficient management.

\section{Methodology}

Survey research design through the administration of questionnaire to respondents was adopted by this study. The target population was 1,500 chartered accountants with public finance experience. Krejcie \& Morgan (1970) formula was used to determine the sample size of 306. The data were analysed with the aid of logit regression technique.

\section{Data Presentation, Analysis and Discussion of Findings}

Model Specification:

$\mathrm{GR}=\mathrm{f}($ EDMP, EMIMI, TAG, IRCEMDS)

$\mathrm{GR}=\mathrm{f}\left(\beta_{0}+\beta_{1}\right.$ EDMP $+\beta_{2}$ EMIMI $+\beta_{3}$ TAG $+\beta_{4}$ IRCEMDS $\left.+\mu\right)$

\subsection{Discussion of Results}

The results were discussed with the test of the hypothesis using the logit regression technique.

- Research Hypothesis: $\mathrm{H}_{0}$ - Domestic debt management has no significant influence on government revenue in Nigeria.

Estimated Model:

From output statistics as shown in table 1 (Model Summary), table 2 (Analysis of Variance - ANOVA), and table 3 (Coefficients), the results of the model specification are:

$\mathrm{GR}=1.163+0.241 \mathrm{EDMP}+0.111 \mathrm{EMIMI}+0.013 \mathrm{TAG}+0.340 \mathrm{IRCEMDS}$

The a priori expectation: $\beta_{0}>0, \beta_{1-4}>0$.

The result of the regression analysis showed how much of the variation in the dependent variable is explained by the variation of the components in the independent variable. The decision rule is that the null hypothesis should be rejected since t-calculated of 0.591 is greater than t-tabulated of 0.560 at $5 \%$ level of significance. Thus, it can be concluded that there is a not too significant positive relationship between Domestic Debt Management and Government Revenue in Nigeria.

This is also indicated by the individual level of significance in table 3 of $0.039,0.045,0.046$, and 0.022 which are less than $5 \%$ acceptable level of significance.

The result also shows that there is positive relationship between the components of independent variables and government revenue - Effective Debt Maturity Policy (EDMP) with positive $\beta_{\text {EDMP }}(0.241)$; Effective Management of Inflation and Monetary Instability (EMIMI) with positive $\beta_{\text {EмIмI }}(0.111)$; Transparency and Accountability in Government (TAG) with positive $\beta_{\text {TAG }}$ (0.013); and Interest Rate Control and Effective Management of Debt Structure (IRCEMDS) with positive $\beta_{\text {IRCEMDs }}(0.340)$ is positive. These imply that the proxies of Domestic Debt Management (DDM) will also individually reduce debt burden on Government Revenue (GR) in Nigeria.

\subsection{The Coefficient of Determination $\left(R^{2}\right)$}

The value of the coefficient of determination $\left(\mathrm{R}^{2}\right)$, was 0.120 . This shows that $12.0 \%$ of the variation in government revenue could be explained by the components of domestic debt management, while the remaining $88.0 \%$ could be because of other variables not accounted for in the model specification. The model in table 3 revealed that the relationship between DDM and GR is not statistically significant $(\mathrm{P}=.528>.05)$ with t-statistics $=0.591$. The adjusted $\mathrm{R}^{2}$ was -0.27 , which is not too close to the $\mathrm{R}^{2}$ value of 0.120 . This indicates that the model is not fit for making generalization. Consequently, domestic debt management (measured by EDMP, EMIMI, TAG, IRCEMDS) has no significant positive effect on government revenue. Therefore, we cannot conclude that a significant difference exists between the variables. Meanwhile, this result contradicts the coefficient in table 3, where the t-calculated of 0.591 is greater than t-tabulated of 0.560 at $5 \%$ level of significance, which implies that the null hypothesis should be rejected. This result is in line with the findings of Imimole \& Imoughele (2012) but having different dependent variable. 


\begin{tabular}{|c|c|c|c|c|}
\hline Model & R & R Square & $\begin{array}{c}\text { Adjusted R } \\
\text { Square }\end{array}$ & $\begin{array}{c}\text { Std. Error of } \\
\text { the Estimate }\end{array}$ \\
\hline 1 & $.346^{\mathrm{a}}$ & .120 & -.027 & .73749 \\
\hline
\end{tabular}

Table 1: Model Summary for Model Specification

a. Predictors: (Constant), EDMP, EMIMI, TAG, IRCEMDS

Source: Authors' Field Work (2020)

\begin{tabular}{|c|c|c|c|c|c|c|}
\hline \multicolumn{2}{|c|}{ Model } & Sum of Squares & Df & Mean Square & F & Sig. \\
\hline \multirow{3}{*}{1} & Regression & 1.774 & 4 & .444 & .816 & $.528^{\mathrm{b}}$ \\
\cline { 2 - 7 } & Residual & 13.053 & 24 & .544 & & \\
\cline { 2 - 7 } & Total & 14.828 & 28 & & & \\
\hline
\end{tabular}

Table 2: ANOVA afor Model Specification

a. Dependent Variable: Government Revenue

b. Predictors: (Constant), EDMP, EMIMI, TAG, IRCEMDS

Source: Authors' Field Work (2020)

\begin{tabular}{|c|c|c|c|c|c|c|}
\hline \multicolumn{2}{|c|}{ Model } & \multicolumn{2}{c|}{$\begin{array}{c}\text { Unstandardized } \\
\text { Coefficients }\end{array}$} & $\begin{array}{c}\text { Standardized } \\
\text { Coefficients }\end{array}$ & \multirow{2}{*}{ Sig. } \\
\cline { 3 - 7 } \multicolumn{2}{c|}{} & B & Std. Error & Beta & & \\
\hline \multirow{3}{*}{1} & (Constant) & 1.163 & 1.968 & & .591 & .560 \\
\cline { 2 - 7 } & EDMP & .241 & .280 & .190 & .861 & .039 \\
\cline { 2 - 7 } & EMIMI & .111 & .338 & .076 & .330 & .045 \\
\cline { 2 - 7 } & TAG & .013 & .189 & .015 & .069 & .046 \\
\cline { 2 - 7 } & IRCEMDS & .340 & .273 & .293 & 1.245 & .022 \\
\hline
\end{tabular}

Table 3: Coefficients ${ }^{\text {for }}$ Model Specification

a. Dependent Variable: Government Revenue

Source: Authors' Field Work (2020)

\section{Conclusion and Recommendations}

Governments resort to the use of public debts to finance deficit budget for economic growth. The conditions attached to foreign loans encouraged the policy shift for domestic borrowings. In the recent times, the upward trend of the internal debt brought about the calls for a more proactive management. Thus, it is expected that an efficient domestic debt management policy will not only improve the revenue of government but will translate to economic growth. The revenue, when efficiently utilized is expected to translate to economic growth. Researches have revealed the diversion of domestic debts to either for personal use or investing this to fruitless projects (Ngerebo-A, 2014; Adofu \& Abula, 2010; Okwori \& Sule; 2016; Eyide \& Nzewi, 2018).

Thus, this study became necessary on the need to ensure probity and accountability of domestic loans for efficient application. This study then examined the nexus between domestic debt management and government revenue in Nigeria. The study shows that between 2009-2018, the domestic debt and the service cost moved upward, resulting in the crowding-out of private investment, increase in unemployment, and drop in the standard of living of the citizens, among others. The study reveals that the efficient management of domestic debt will improve the revenue of government but not too significantly. The results also reveal that there is positive link between domestic debt management, proxied by the respective sub independent variables and government revenue in Nigeria. Consequently, the presence of efficient management of internal loans will reduce the negative impact of this on government revenue for improved citizens' standard of living, among others. In view of the findings, the following recommendations are made:

- Government should redefine and reassess the domestic debt management policy for a more robust and efficient one.

- Government should reshuffle its domestic debt management team for a more efficient and proactive one, which will comprise of all stakeholders including the academia.

- Government should subject every request for domestic loans to critical and objective public scrutiny to prevent contracting avoidable debts.

- Experienced private entrepreneurs should be engaged by the government in advisory capacity to the government on matters of domestic debt borrowings.

- Government should have an effective engagement with the internal creditors for a better agreement in form of loan conversion, and loan rescheduling, among others.

\section{References}

i. $\quad$ Adofu I. \& Abula M. (2010). Domestic Debt and Nigerian Economy. Current Research Journal of Economic Theory, 2 (1), 22-26.

ii. Ayuba, I. K. \& Khan, S. M. (2019). Domestic Debt and Economic Growth in Nigeria: An ARDL Bounds Test Approach. Sciendo Riga Technical University Economics and Business, 33, 50-68.

iii. Domestic Management Office (DMO). Annual Reports and Financial Statements for 2009-2018. https://www.dmo.gov.ng. 
iv. Dooley, M. P. (2000). Debt Management and Crisis in Developing Countries. Journal Of Development Economics, 63, 45-58.

v. Essien, S. N., Agboegbulem, N. T. I., Mba, M. K. \& Onumonu, O. G. (2016). An Empirical Analysis of the Macroeconomic Impact of Public Debt in Nigeria. CBN Journal of Applied Statistics, 7 (1a), 125-145.

vi. Ewubare, D., Nteegah, A. \& Okpoi, G. (2017). Public Borrowing and the Nigerian Economy: An Autoregressive Distributed Lag Model (ARDL) Approach. The International Journal of Social Sciences and Humanities Invention, 4 (5), 3506-3514.

vii. Eyide, M. U. \& Nzewi, U. (2018). Debt Management and Economic Development In Nigeria (1981-2016). International Accounting and Taxation Research Group, Faculty of Management Sciences, University of Benin, 4.0, 75-90. www.atreview.org

viii. $\quad$ Fasoye, K. (2018). Nigeria's Domestic Debt Profile (1980-2017). Historical Research Letter, 47, 9-13.

ix. Irabor, E. P. (2011). Internal Debt Management Problems of Sustainable Economic Development Process in Nigeria. Multidisciplinary Journal of Research Development, 11 (4), 1-9.

x. Imimole, B. \& Imoughele, L. E. (2012). Impact of Public Debt on An Emerging Economy: Evidence from Nigeria (1980-2009). International Journal of Innovative Research \& Development, 1(8), 242262.

xi. $\quad$ Karazijiene, Z. (2015). Critical Analysis of Public Debt and Tendencies of Its Management. Public Policy and Administration, 14(2), 194-208.

xii. Jeanne, O. \& Guscina, A. (2006). Government Debt in Emerging Market Countries:A New Data Set. International Monetary Fund (IMF) Working Paper, WP/06/98, 1-29.

xiii. Missale, A., Giavazzi, F. \& Benigno, P. (2002). How is the Debt Managed? Learning From Fiscal Stabilizations. The Scandinavian Journal of Economics, Macroeconomic Risk, Policies and Institutions, 104(3), 443-469. https://www.jstor.org/stable/3441034?seq=1

xiv. Ngerebo-A, T. A. (2014). Domestic Debt and Poverty in Nigeria: An Empirical Time Series Investigation. European Journal of Accounting, Auditing and Finance Research, 2 (5), 33-47.

xv. Okwori, J. \& Sule, A. (2016). Revenue Sources and Economic Growth in Nigeria: An Appraisal. Journal of Economics and Sustainable Development, 7(8), 113-123.

xvi. Osodiuru, P. E. C., Odo, A. C., Ugwuoke, A. C. \& Chikwendu, N. F. (2018). Examining the Richardian Equivalence Hypothesis in Nigeria using an ARDL Bound Testing Approach. International Journal of Scientific Research and Innovative Technology, 5(8), 45-59.

xvii. Panizza, U. (2008). Domestic and External Public Debt in Developing Countries. United Nations Conference on Trade and Development (UNCTAD) Discussion Papers, 188, 1-20.

xviii. Raifu, I. A. \& Raheem, A. N. (2018). Do Government Revenues Matter for Economic Growth? Evidence from Nigeria. European Journal of Government and Economics, 7(1), 60-84.

xix. $\quad$ Ricciuti, R. (2001). Assessing Ricardian Equivalence. Societa Italiana di economia Pubblica Working Papers March 2001, 1-34.

xx. Ude, D. K. \& Ekesiobi, C. S. (2014). Domestic Debt and Private Investment in Nigeria. International Journal of Scientific Research and Education, 2 (8), 1533-1540.

xxi. Yusuf, B.R., Idowu, K.A., Okunnu, M.A. \& Adeyemi, O.T. (2010). Debt Management and Economic Growth in Nigeria: Performance, Challenges and Responsibilities. Information Management, 12, 31-39. 